\title{
STUDENTS' PERCEPTION OF SNOWBALL THROWING IN TEACHING GRAMMAR
}

\author{
Yanuarti Apsari $^{1}$, Indra Andriana Saputra ${ }^{2}$, Gian Leriandini ${ }^{3}$ \\ ${ }^{1}$ IKIP SILIWANGI \\ ${ }^{2}$ IKIP SILIWANGI \\ ${ }^{3}$ IKIP SILIWANGI \\ ${ }^{1}$ yanuar.apsari1@gmail.com, ${ }^{2}$ indrasaputrais090@ gmail.com, ${ }^{3}$ gianleriandini@gmail.com
}

\begin{abstract}
The aim of the research is to investigate students' perception of snowball throwing technique in teaching grammar. The research used qualitative descriptive research method and the participants of the research were second grade of SMPN 2 Padalarang. The data were obtained from questionnaire and interview. Questionnaire was used to obtain information about students' perception towards the implementation of snowball throwing in teaching grammar and interview was also used to get more specific information that cannot be accessed through questionnaire. From the questionnaire, the students answered strongly agree is $66,67 \%$, agree $19,44 \%$ and disagree $13,89 \%$ that this technique is good to be implemented in teaching grammar. Therefore, the result shows that the implementation of snowball throwing technique in teaching grammar can help students to learn English grammar. Based on questionnaire and interview, they enjoyed learning with this technique and they showed some improvement on their participation of learning activity, their their creativity and their cooperative skill when learning with this technique.
\end{abstract}

Keywords: Grammar, Snowball Throwing Technique, Students' Perception

\section{INTRODUCTION}

Grammar is one of the micro skills of English. Grammar is the structure of language to organize meaning. It is used in everyday communication in order to shows ideas and feelings. It is the combination of phrases, clauses or sentences. We realized that it impact in all English basic skills they are listening, speaking, reading and writing. Students must know whether their sentences use correct pattern or not when they speak or write. They also must be comprehend whether the sentences they listen or read is correct or not. They must mastering grammar because it is a crucial aspect in English.

Mastering English grammar becomes crucial since different patterns impact the meaning of the sentences. This is in line with Strumpf \& Douglas (2004:14) that said "we study grammar so that we may speak and write in a clearer and more effective manner." This means that the students must know how to compile a correct pattern in order to minimize misunderstanding in sharing ideas or information. When the students could not master grammar, they may find a lot of difficulties in sharing their ideas or information. In other words, teaching English grammar has important role since it become one of the main micro skills that must be mastered.

However, the students at second grade of junior high school in Indonesia face some difficulties in learning grammar due to English is not their first language. Besides, English grammar has different pattern and function. To cope this problem, the researcher applied one 
of the teaching model namely cooperative learning in the form of snowball throwing technique in order to help students in learning grammar.

\section{Teaching Grammar}

In teaching grammar, they are several goals proposed by Haussamen (2003):

1. Students from different background can get the ability to communicate comfortably and effectively;

2. Students can analyze the grammatical structures of sentences, correctly use grammatical terminology;

3. Students can understand and appreciate the natural variation that occurs in language impact by time, social situation and social group.

To achieves goals above, teacher should choose appropriate approach, method or technique in teaching grammar. Haussamen (2003) states that "there are two general approaches for helping students discover grammar: contrasting two types of language with the same or similar content and using authentic texts to observe the grammatical aspects of actual written English."

Besides, Mart (2013) states that teaching geammar in context will allow learners to see how the rules can be used in sentences. As states by Thornbury (1999: 69) "language is context sensitive. This means that, in the absence of context, it is very difficult to recover the intended meaning of a single word or phrase".

Zarifi \& Thagavi (2016) revealed that cooperative learning can work better than traditional learning approach in helping the students to acquire the grammatical knowledge. Ghaith (2003) says that cooperative learning also enabled the EFL learners to perform either significantly better than the whole-class learners or at the same level of them.

Teachers can choose those approaches above in teaching grammar. In this research the researcher conducted cooperative learning approach in teaching grammar in the form snowball throwing technique.

\section{Teaching Grammar through Snowball Throwing}

Teaching grammar through snowball throwing is one of technique that can be used to improve students' grammatical competence. As stated by Apsari (2018) snowball throwing in teaching grammar has some benefits; improving students' comprehension in learning grammar, creating enjoyable learning atmosphere, increasing students' vocabulary, developing students' speaking skill, developing students' cooperation skill and increasing students' participation in the class.

Snowball throwing technique is a technique that is developed from cooperative learning approach. This technique use paper ball containing questions then, the ball is thrown to another group and group that got a ball should answer the question. This technique has several steps as proposed by Apsari (2018) :

1. Preparing teaching material

2. Forming group

3. Reexplaining the material to the member of the group

4. Formulating questions

5. Tossing the ball 
6. Answering the questions

7. Evaluating teaching and learning process

The stages of snowball throwing technique in this research adopted from Apsari (2018).

\section{Students' Perceptions}

According to Robbins \& Judge (2013: 166), "Perception is a process by which individuals organize and interpret their sensory impressions in order to give meaning to their environment. In addition, Mussen (1973) states that perception is the process of acquiring information through sensory receptors that is transformed into a perception of what we think, see, hear, smell, taste, or touch.

Human can interpret information in different way even they get same information with others. It can be occurs due to factors of situation (time, work setting and social setting), factors in the perceiver (attitudes, motives, interests, experiences and expectations) or factors in the target (novelty, motion, sounds, size, background, proximity and similarity). (Robbins \& Judge, 2013:167)

From the explanation above we can conclude that students' perception is the way how their impression about the technique that researcher used in teaching grammar.

\section{METHOD}

This research used qualitative descriptive method. This research was conducted at one of junior high school in Padalarang. The participants of this research were students at the second grade of SMPN 2 Padalarang. The data of this research was obtained based on the results of classroom questionnaire and interviews. Questionnaire was used to obtain information about students' perception towards the implementation of snowball throwing in teaching grammar. The questionnaire and interview were conducted on January 2019.

Besides, interview was also used to get more specific information that cannot be accessed through questionnaire. Interview was conducted individually so that the researchers can expand the questions. The interview was involved six students consisting of high, average and low score students. Then, to obtain data validation, the researchers combined various findings from questionnaire and interviews.

\section{RESULTS AND DISCUSSION \\ Results}

This table below is the table of questionnaire and the results for students perception of snowball throwing in teaching grammar:

Table 1. Result of Questionnaire

\begin{tabular}{|c|c|c|c|c|c|c|}
\hline Category & Number & Question & $\begin{array}{c}\text { Strongly } \\
\text { agree }\end{array}$ & Agree & Disagree & $\begin{array}{l}\text { Strongly } \\
\text { disagree }\end{array}$ \\
\hline $\begin{array}{l}\text { 1. Student } \\
\text { Perception } \\
\text { toward }\end{array}$ & 1. & $\begin{array}{l}\text { I feel easy } \\
\text { learning with this } \\
\text { technique }\end{array}$ & $80,56 \%$ & $19,44 \%$ & - & - \\
\hline $\begin{array}{l}\text { Snowball } \\
\text { Throwing }\end{array}$ & 2. & $\begin{array}{l}\text { I understand } \\
\text { lessons more }\end{array}$ & $63,89 \%$ & $36,11 \%$ & - & - \\
\hline
\end{tabular}


Technique

Benefit of

Snowball

Throwing

Technique quickly using this

technique

\begin{tabular}{llllll}
\hline 3. & $\begin{array}{l}\text { I feel enjoy and } \\
\text { active learning } \\
\text { with this } \\
\text { technique }\end{array}$ & $41,67 \%$ & $58,33 \%$ & - & - \\
\hline $4 . \quad$ & $\begin{array}{l}\text { I get new } \\
\text { information } \\
\text { through this } \\
\text { technique }\end{array}$ & $27,78 \%$ & $72,22 \%$ & - & - \\
& & & & & \\
\hline $5 . \quad \begin{array}{l}\text { I love learning } \\
\text { grammar by using } \\
\text { this technique }\end{array}$ & $83,33 \%$ & $16,67 \%$ & - & - \\
\hline $6 . \quad \begin{array}{l}\text { I can get more } \\
\text { information using } \\
\text { this technique }\end{array}$ & $27,78 \%$ & $72,22 \%$ & - & - \\
\hline & & & & \\
\hline
\end{tabular}

the material

through this

technique

\section{I feel happy to $88,89 \% \quad 11,11 \%$}

learn through this

technique

9. I can learn $75 \% \quad 25 \%$

quickly and easily

\begin{tabular}{lllll}
\hline 10. & $\begin{array}{l}\text { My creativity is } \\
\text { improved through } \\
\text { this technique }\end{array}$ & $36,11 \%$ & $50 \% \%$ & $13,89 \%$
\end{tabular}

\begin{tabular}{|c|c|c|c|c|c|c|}
\hline \multirow{4}{*}{$\begin{array}{l}\text { 3. The } \\
\text { Weakness } \\
\text { of Snowball } \\
\text { Throwing } \\
\text { Technique }\end{array}$} & 11. & $\begin{array}{l}\text { I do not } \\
\text { understand when i } \\
\text { learn through this } \\
\text { technique }\end{array}$ & - & $13,89 \%$ & $86,11 \%$ & - \\
\hline & 12. & $\begin{array}{l}\text { This method is } \\
\text { less fit to use at } \\
\text { the time of } \\
\text { learning }\end{array}$ & - & - & $25 \%$ & $75 \%$ \\
\hline & 13. & $\begin{array}{l}\text { I feel bored } \\
\text { quickly }\end{array}$ & - & - & $5,56 \%$ & $94,44 \%$ \\
\hline & 14 & $\begin{array}{l}\text { I prefer learning } \\
\text { by way of }\end{array}$ & - & - & $30,56 \%$ & $69,44 \%$ \\
\hline
\end{tabular}




\begin{tabular}{|c|c|c|c|c|c|}
\hline & $\begin{array}{l}\text { discussions, } \\
\text { lectures etc, rather } \\
\text { than using this } \\
\text { technique }\end{array}$ & & & & \\
\hline 15. & $\begin{array}{l}\text { I can not improve } \\
\text { my creativity } \\
\text { through this } \\
\text { technique }\end{array}$ & - & $13,89 \%$ & $36,11 \%$ & $50 \%$ \\
\hline
\end{tabular}

The table of questionnaire were divided into three parts in each category and it covers fifteen questions and dealt with classroom interaction. One sheet of the questionnaire is for one student.

\section{Discussion}

a. Students' perception toward snowball throwing activity

The first part of the questionnaire is the students' perception towards the activity in the classroom when snowball throwing was implemented in learning grammar. This part contained five questions and the results shows that the students enjoyed learning grammar through this technique, they interested in learning activity and they can improve their participation when using this method as admitted by student 1 :

This technique is interesting and I can share my opinion with my friends and I am not shame to speak English when discussing with my group.

(S1) (interview, translated version)

We can conclude that when snowball throwing is implemented in learning grammar, students were interest to this technique and they were enjoyed while teaching and learning process occur.

b. Students' perception toward the benefits of snowball throwing

The second part of the questionnaire is the students' perception towards the benefits of snowball throwing when it was implemented in learning grammar. This part contained five questions and the results shows that they can get more information while this technique was implemented. They can learn the material easily since students with a good intellegence were helped students that do not understand yet the materials. Many students can follow the instruction that teacher gave, their creativity was improved as admitted by student 2 :

Through this technique, I can answer the question with my friends' helped. And my creativity was improved when we should make questions for another group.

(S2) (interview, translated version)

Istarani (2012) states that one of the benefits of snowball throwing develops creativity of the students when they must be create the questions and form their paper into a ball.

c. Students' perception toward the weakness of snowball throwing

The last part of the questionnaire is the students' perception towards the weakness of snowball throwing when it was implemented in learning grammar. This part contained five questions and the results shows that some student do not understand while this technique was implemented and they cannot improve their creativity through this technique impacted by some factors as admitted by student 3 :

I cannot understand well when learning through this technique because I lack of vocabulary and I do not paid attention well to you and I do not read the vocabulary 
that you gave to me. And my creativity was not improved because I did not work well with my group.

(S3) (interview, translated version)

There were some weakness that students disagree they were this technique is not suitable with the time of learning, they prefer learning use this technique than learning use conventional technique. We can summarized that this technique has some weakness but majority students can get some benefits from this technique.

\section{CONCLUSION}

The conclusion of this research is this technique is good to implement when teaching grammar. Mostly students are enjoyed and active when learning grammar through this technique and they can improve their participation in classroom activity while the teaching and learning process occur. Besides generally they can improve their creativity when learning by this technique. This technique use questionnaire and interview to gather the information from the students. From the questionnaire, the students answered strongly agree is $66,67 \%$, agree $19,44 \%$ and disagree $13,89 \%$. They claimed that they very enjoyed and interesting when learning by this technique. For the interview, the student answered disagree have an opinion from his statement "I cannot understand the material because I do not like to learn English". From her statement, the researcher give motivation to her to like English because the importance of it. Overall, mostly students were enjoy and active when learning grammar through this technique. Also, this technique can improve students participation in classroom activity because they have to work with their group to create a question for another group and answer the question from another group.

\section{ACKNOWLEDGMENTS}

All praise goes to Allah S.W.T who has given us grace and affection. As well as giving us the opportunity to complete this research. This research was supported by our campus IKIP Siliwangi, our beloved lecturers who always give us their guidance and knowledge and also our beloved family and friends. We are thankful to your support in the writing process of this research

We are also grateful to Mrs. Yanuarti Apsari who always give us her guidance and help to write this research. We have to express out appreciation to all who have been involved in writing and publishing this research, for their comments on an earlier versions of the manuscript.

\section{REFERENCES}

Apsari, Y. (2018). Snowball Throwing in Teaching Grammar. Lingual, 10(1), 52-59.

Ghaith, G. M. (2003). The Relationship between Form or Intruction, Achievement and Perception of Classroom Climate. Educational Research, 45, 83-93.

Haussamen, B. (2003). Grammar Alive! Urbana, IL: National Council of Teachers. 
Mart, C. (2013). Teaching Grammar in Context: Why and How? Theory and PPactice in Language Studies, 3(1), 124-129.

Mussen, P. (1973). Psychology: An Introduction. Toronto: D.C. Health and Company.

Robbins, S. P., \& Judge, T. A. (2013). Organizational Behavior (15th ed.). New York: Pearson Education.

Strumpf, M., \& Douglas, A. (2004). Golden's Concise English Grammar. Kuala Lumpur: Golden Book Centre SDN.

Thornbury, S. (1999). How to Teach Grammar. Essex: Pearson Education Limited.

Zarifi, A., \& Thagavi, A. (2016). The Impact of Cooperative Learning on Grammar Learning Among Iranian Intermediate EFL Learners. Theory and Prractice in Language Studies, 6(7), 1429-1436. 